\title{
Somogy megye tőröslegyeinek katalógusa (Diptera: Therevidae)
}

\author{
TÓTH SÁNDOR
}

Tóth S.: Checklist of stiletto flies of Somogy county (Diptera: Therevidae)

Abstract: The stiletto fly fauna of Somogy county has not been regularly investigated. According to the poor literature available, 11 species (one third of the taxa in Hungary) can be proved to exist in the County. There are no rarities among them. From the relatively rare stiletto flies living in sandy area, only the Cliorismia ardea (Fabricius, 1794) is worth mentioning.

\section{Bevezetés}

Magyarország tôröslegyeit csak nagyon hézagosan ismerjük. Az eddig kimutatott 32 faj valószínúleg csak mintegy kétharmada a tényleges faunának. Somogy megyében még kedvezôtlenebb ez az arány, mivel a szegényes irodalom alapján a megyéből mindössze 11 faj előfordulását tekinthetjük igazoltnak. A rendelkezésre álló adatok nagyrészt a Duna-Dráva Nemzeti Parkból, a Boronka-melléki Tájvédelmi Körzetból és a Zselicból származnak. Csupán egyetlen faj (Thereva aurata Loew, 1854) régebbi somogyi irodalmi adata származik Fonyódról (SZILÁDY 1941).

A megyében folyó kutatások során kiemelkedô ritkaságot eddig nem sikerült találni. A viszonylag ritka, homokos területekre jellemzó tőröslegyek közül is csupán a Cliorismia ardea (Fabricius, 1794) érdemel említést.

\section{A Somogyból ismert fajok jegyzéke}

Ammothereva laticornis (Loew, 1856) - Csiby 1981, Tóth 1995. Szórványos elófordulású, elsősorban az Alföld lakója.

Cliorismia ardea (Fabricius, 1794) - Csiby 1981, Tóth 1992, 1995. Magyarország kevés helyen, elsősorban homokos területeken található. 1981

Thereva apicalis Wiedemann, 1821 - Csiby

Thereva aurata Loew, 1854 - Csiby 1981, Szilády 1941 (Fonyód). Fóleg domb- és hegyvidékeken fordul elố.

Thereva cincta Meigen, 1820 - Csiby 1981
Thereva fulva (Meigen, 1804) - Csiby 1981, Tóth 1992. Szórványos elófordulású, elsôsorban domb- és hegyvidékekre jellemzô.

Thereva marginula Meigen, 1820 - Csiby 1981, Tóth 1992

Thereva nobilitata (Fabricius, 1775) - Tóth 1992. Szórványos elôfordulású, föleg hegyvidékeken él.

Thereva praecox Egger, 1959 - Csiby 1981

Thereva rustica Loew, 1840 - Tóth 1992

Thereva valida Loew, 1847 - Csiby 1981, Tóth 1992. Szórványos elófordulású, a hegyvidéken gyakoribb. 


\title{
Irodalom
}

CsıBY M. 1981: Adatok a Barcsi Borókás kétszárnyú (Diptera) faunájához - Dunántúli Dolg. Term. tud. Sorozat 2: 149-156.

SzıLÁdY Z., 1941: Diptera-kutatás a Balaton környćkén - Magyar Biol. Kut. Munk. 13: 259-267. Tótr S., 1992: Vegyes kétszárnyú (Diptera) adatok a Boronka-melléki Tájvédelmi Körzet faunájához - Dunántúli Dolg. Term. tud. Sorozat 7: 273-287.

TớrH S., 1995: Adatok a Dráva mente kétszárnyú (Diptera) faunájához-Dunántúli Dolg. Term. tud. Sorozat 8: 161-172.

\section{Checklist of stiletto flies of Somogy county \\ (Diptera: Therevidae)}

\section{SÁNDOR TÓTH}

Our knowledge about the stiletto flies in Hungary is incomplete. The 32 species recorded so far is only two thirds of the actual fauna. In Somogy county this ratio is even worse, since only $1 \mathrm{l}$ species can be proved to exist in the County on the basis of the poor literature available on the subject. The available data mostly covers the area of the Duna-Dráva National Park, the Boronka-melléki Landscape Protection Area and the Zselic. The data of only one species (Thereva aurata Loew, 1854) originates from Fonyód (SZILÁDY 1941). During the surveys in the county, no significant rare species were collected. From the relatively rare stiletto flies living in sandy area, only the Cliorismia ardea (Fabricius, 1794) is worth mentioning.

\author{
Author's address: \\ Dr. Sándor Tóth \\ H - 8420 Zirc \\ Széchenyi u. 2. \\ HUNGARY
}

